\title{
THE CONVERSATION
}

Academic rigor, journalistic flair

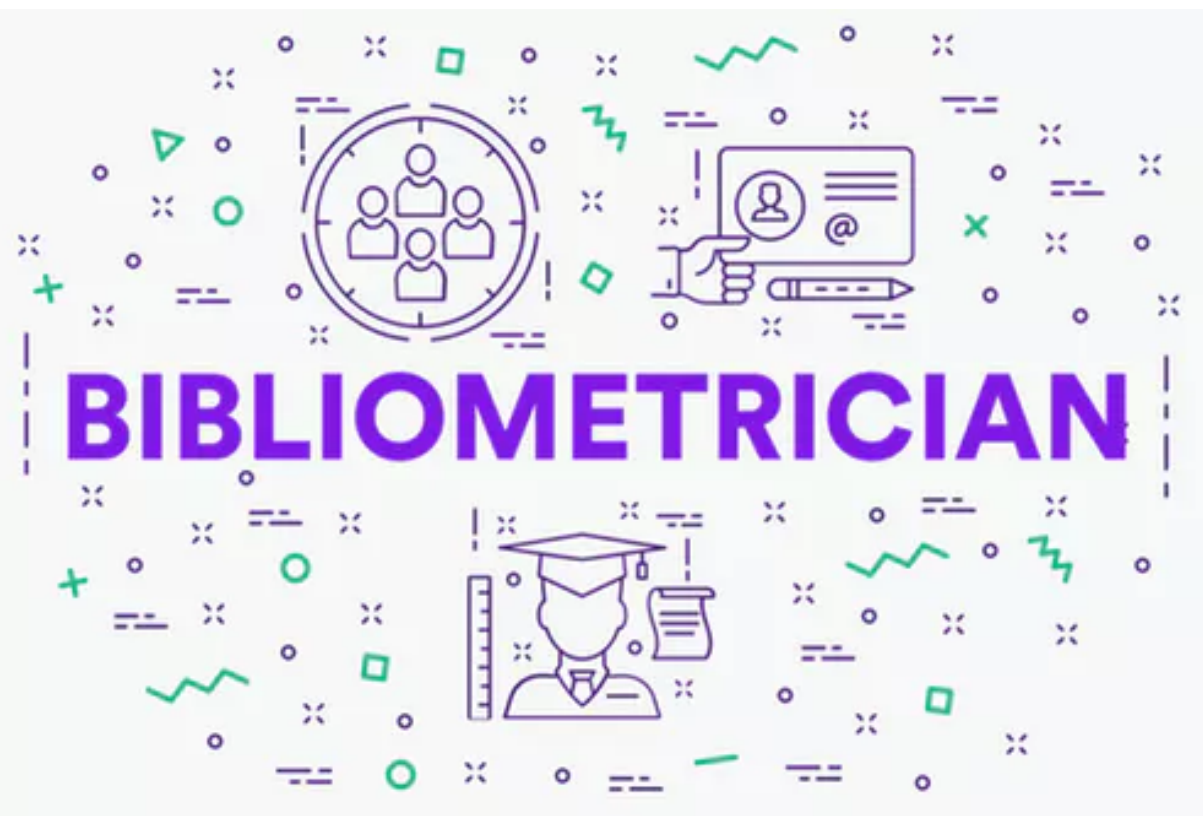

\section{Jalan evolusi bibliometrik Indonesia}

January 8, 2019 3.55am EST

When quantitative indicators are used as the basis for decision making, these indicators are vulnerable to manipulation. OpturaDesign / Shutterstok

\section{The path of Indonesian bibliometric evolution}

January 8, 2019 3.55am EST

In 2017 the Ministry of Research, Technology and Higher Education

(Kemristekdikti) launched SINTA ( Science and Technology Index ) , a

bibliometric system for recording and analyzing scientific documents and citations of scientific works of scientists, lecturers and researchers. This system is used to measure the performance of academics and research institutions in Indonesia, and to determine who will get research funding .

Unfortunately, the bibliometric system by including Scopus, Elsevier 's commercial database and the dominant weighting for the number of documents and citations, made SINTA ineffective in measuring Indonesia's research and development. In fact, this system can risk pushing Indonesian academics to violate scientific ethics and academic corruption.

\section{Authors}

Juneman Abraham

Head of Research and Publication, Himpunan Psikologi Indonesia 


\section{Indicator dogma}

Research transforms knowledge into science that contributes to the meaning, explanation, prediction, and control of various problems in our lives. Good research can improve people's welfare .

Surya Dalimunthe

Peneliti Sains Terbuka dan Studi Islam,

Universitas Islam Sumatera Utara

Kemristekdikti aspires to build regions with research and innovation , as in

other developing countries in Africa and Central America .

To help policymakers make decisions about research and development many countries are trying to create a measurement system (biliometrics) to evaluate the performance of the research sector. The indicator measured in bibliometrics is the output of research as a proxy for procedures, processes, and evolution of research .

\section{Read more: The cobra effect, Indonesian lecturers are obsessed with the Scopus index and despicable practices towards world-class universities}

More than 150,000 Indonesian academics are registered in the SINTA bibliometric system. But bibliometric-based measurement systems have been found to be problematic. Representation of research outputs on quality is still limited to assumptions, because, "quality" of a research is an abstract concept that is still difficult to recognize by bibliometrics.

A lot of evidence around the world shows that manipulating indicators, both in groups and individually, often occurs in bibliometric systems . More specifically, the use of business entity-made metrics began to be questioned and even sued in the Western world.

The prevalence of such behaviors in various application indicators and measures has led to Campbell's adage : "When quantitative indicators are used as a basis for decision making, these indicators are vulnerable to manipulation by the parties affected by the decision", and Goodhart's adage : no longer useful ".

\section{Incentives for manipulation}

This is what seems to be happening in Indonesian researchers. Because the rankings of academics are based on the SINTA score, they have difficulty focusing on developing science, and are busy pursuing indicators.

Scopus is now very important for the success of academic careers in Indonesia. This is because SINTA "copies data from articles or publications from Scopus" and gives it the greatest weight, both the number of documents and citations. For this reason, researchers need to have a Scopus ID with a minimum entrance of one document on Scopus.

The government also encourages managers of domestic scientific journals who wish to pass the accreditation of national scientific journals (ARJUNA), to prioritize editors and reviewers 
who have Scopus ID as journal personnel and prioritize Scopus ID information on the journal editorial team's profile.

| sinta2.ristekdikti.go.id/home/faq\#ans3

\section{Cisinta}

Frequently Asked Questions

1. Bagaimana Pendaftaran Penulis (Author) di SINTA?

2. Bagaimana Jurnal dapat Terindeks di Sinta dan Bagaimana Penilaiannya?

3. Bagaimana Sinta Score untuk Aurhor dihitung?

Berikur komponen perhitungan dan formula perhitungan Sinta Score untuk Dosen/Peneliti

\begin{tabular}{lll} 
Komponen Penilaian & Kode & Bobot Penilaian (bukan persentase) \\
\hline Jumlah Dokumen Arrikel di Scopus & A & 40 \\
\hline Jumlah Dokumen Non-Artikel di Scopus & B & 15 \\
\hline Jumlah Sitasi di Google Scholar & C & 1 \\
\hline Jumlah Sitasi di Scopus & D & 4 \\
\hline Kualiras H-Index (Google Scholar) & E & 4 \\
\hline Kualiras H-index (Scopus) & F & 16
\end{tabular}

Formula Sinta Score: $((\mathrm{A} \times 40)+(\mathrm{B} \times 15)+(\mathrm{C} \times 1)+(\mathrm{D} \times 4)+(\mathrm{E} \times 4)+(\mathrm{F} \times 16)) /$ Pembagi

Pemhagi adtalah cehuah anok a hacil dari nerhitunean cratictik vang memnertimhanekan maksimum Sinta Srnre Percnnal/Dnsen/Penpliti Tertinggi

The SINTA score formula that was hunted by a number of Indonesian scientists. SINTA

\section{The emergence of the conference industry}

Some things that prevent Indonesian researchers from publishing scientific articles in Scopus indexed journals include including no Indonesian language journals indexed by Scopus - this is an obstacle for Indonesian academics whose ability to write English is limited.

In addition, generally scientific journals indexed by Scopus require a fairly high article processing fee, especially if you want to publish with open access in large publishers . Finally, some researchers are nervous about the peer review process that must be passed to publish their scientific articles.

To overcome this, most Indonesian academics have increased publications indexed by Scopus through academic conferences that have produced Scopus indexed proceedings. This conference can be held at a relatively affordable cost .

Proceedings articles are publications published in the context of conferences, seminars and workshops. Because of its short and more informal nature, it is different from articles in scientific journals, although indexed by Scopus proceedings articles are published without going through an adequate peer review process. 
Peer review is important because science does not live in a vacuum . The quality of an article reviewed by colleagues who have expertise in the field of articles, in terms of argumentation, methodology and analysis, is more assured .

Regarding the review process, generally foreign proceedings connected with Scopus only carry out a superficial review process (for example related to the layout and style of the environment) or even none at all because the review process has been submitted to the organizers of the event and activities .

In SINTA, the Scopus indexed proceedings of three proceedings have been able to replace and even exceed one journal article.

The creation of new industries as a result of this regulation, namely in the form of organizing events such as the conference above.

\section{Misuse of citations}

SINTA's focus on the number of citations has encouraged academics to violate ethics. They do this through their own work citations and collaborative citations that are irrelevant and excessive.

Kemristekdikti is also aware of this. On December 19, 2018, the Ministry issued a Data Quality Check Notification Letter at SINTA and stated that there had been ethical violations by several academics.

Not long after that some SINTA accounts were frozen . Even researchers who previously got the highest SINTA score recorded the number of Scopus publications to zero. There are also SINTA accounts which are abolished ( rank) SINTA.

\section{Great potential for the emergence of false authority}

With the current system, information on a person's "expertise" at SINTA is not guaranteed objectively and representative. Ludo Waltman, a bibliometric researcher from CWTS Leiden University, believes that SINTA provides strong motivation for the addition of writers who do not have contributions .

SINTA does not weigh differently in scoring between the author ( author ) and co-author (coauthor ). So a writer can add anyone's name as a companion writer. The co-author will get the same SINTA score as the writer.

This is the dark side of social relations in science, namely mutual cooperation to help or "lift" instant colleagues who actually have no contribution. This fact flourished even more in collectivistic scientific societies such as Indonesia, which were also structurally burdened with quantitative targets. This can be further stimulated by the launch of the field of interdepartmental scoring competition . 
In addition, someone who is registered at SINTA can also directly edit (add, reduce, change) as desired the subject or the research area, through Author Login, without verification from related associations / scientific communities / professions .

Dimensions has an algorithm that can detect research areas that indicate expertise based on research articles ( article based ), not from journals / proceedings where articles are published ( journal-based ). Adopting the practice of Dimensions by SINTA in this context can be a way of blocking fraud expertise.

False authority in an academic system can result in academic corruption. Academic corruption is an umbrella term that shows resistance to integrity, meritocracy (a system of appreciation to the decent), and moral values of education, and the collapse of democratization of knowledge .

In the world of scientific publications, academic corruption can be in the form of groups of people outside the scientific community (such as accreditors, administrators, even faculty committees) who have power and determine the value, contribution, price, and impact of ideas published in journals. The economic value of the publication points in Scopus, when juxtaposed with the gap of industrialization in the world of education, abusive citation, and false authority, presents the potential for academic corruption.

\section{The quality of research is stagnant}

The use of Scopus as a quality filter can not work under these conditions. This can be one explanation why in the midst of the fact that Scopus Indonesia's quantity of publications is encouraging, surpasses Singapore and Thailand, but only three Indonesian universities are ranked in the top 500 in the world.

That is, the number of Indonesian universities that are ranked as immovable world is in line with the growth in the number of publications, although SINTA and QS world-class university rating agencies both use Scopus basic materials.

Indonesia has a program by using public funds to surpass Malaysia in the number of Scopus publications, or what is referred to as "ASEAN Ambition" . Malaysian academics themselves do not seem to perceive this "number race". They exclude proceedings as well as the article's publication review article ( review ) when evaluating research performance of higher education Malaysia.

\section{What is the next step?}

The participation of Scopus identity on the SINTA front page can be replaced with the ORCID identity . This identity, besides being obtained without costs, also fulfills the function of internationalization and mapping the contributions of peer review in science.

ORCID is a means of measuring open and humanistic research achievements that includes not only the element of publication, but also the human element, organization, and resources 
involved in it. This identity is capable of displaying the performance of lecturers and researchers with broader data sources, moreover Kemristekdikti has established a relationship with ORCID since 2017.

Thus the vulnerability of a system of productivity measures and the reputation of lecturers / researchers to "be tricked" can be significantly reduced .

What is needed by the Indonesian research world is pluralism in bibliometrics that is able to measure input, process, outcome, and impact of research. Experimental and in-depth studies need to be held, as well as involving Pre-SINTA period data , in order to produce Indonesian bibliometric databases with the right algorithm.

In that case, Sinta need to record and comparing the outcomes of research with a number of research and development ( $R \& D$ Statistics ) such as funding, the level of academic freedom, activity, and various contexts experienced researchers shared environment. At least as a transition to the freedom of the Indonesian academic world from the measures of research performance that put forward the metric-quantitative aspects.

Large funds that have been poured out by a number of higher education institutions to pursue the number of publications and Scopus citations as SINTA score makers should be partially transferred to finance the study as inter-agency collaboration.

For now, it is urgent for SINTA to change its orientation from the rating system based on the number of publications and citations to become providers of publication data and independent citations that do not depend on commercial databases .

This is critical because access to citations and references is a backbone of the quality of research and the need for the integrity of human knowledge which should be a public good . In fact, SINTA can now display the number of citations, but it cannot produce information behind that number.

Thus, SINTA has not fulfilled the function of relations that are sufficient to map expertise . Negotiating and even asking a commercial publisher to open up citation data is a good choice to increase SINTA.

In addition, SINTA needs to issue articles that come from: journals that are indicated to violate ethics, blacklisted journals, and proceedings and journals that are included in negative findings that are not recognized for academic promotion because they are considered to be of insecure quality .

Better yet, based on the two adage above, if the ranking on SINTA is completely eliminated because science is a matter of changing the fate of humanity, the matter of communication and nurturing, not about making walls and securing your place on the scoreboard .

\section{The response of the Kemristekdikti}


Sadly, the Director of Management of Intellectual Property of the Ministry of Research, Technology and Higher Education, which was asked for a response by The Conversation, stated that his party was ready to accept criticism for the goodness of SINTA and the progress of Indonesian research. "If there is something wrong and cheating in using SINTA, don't turn it off, but fix it," he said. The SINTA team is developing a system of detection of fraud and integrity.

The ministry, he said, will continue to use SINTA because this Indonesian-made system collects researchers' profiles by combining several indices from several sources. Because SINTA is still new, of course there are weaknesses that need to be corrected. "If you only use ORCID, there is also no filter," he said.

Ocky Karna Radjasa, Director of Research and Community Service, said his ministry will continue to evaluate the use of SINTA, including the existence of such fraud. The ministry, he said, will continue to use SINTA because the bibliometric system can document publications both indexed and not indexed in Scopus, accredited or not accredited, books, intellectual property rights and community service by lecturers and researchers.

"Publication of research results is only one of the research outputs, later there will be intellectual property rights, patents, policy recommendations, and others," Ocky said. "We will continue to use SINTA while continuing to encourage the improvement of the quality of research." 